\title{
The Internet and Quality Social Studies Education for Sustainable Development in Post-Covid-19: a Review
}

\author{
Sunday Obro \\ Department of Social Science Education, Delta State University, Abraka, Delta State, Nigeria \\ Corresponding author's email: sobro@delsu.edu.ng
}

Received: 21 March 2021; Revised: 27 March 2021; Published: 30 March 2021

\begin{abstract}
The Internet has its fundamental prerequisite needed by all to outlive the challenges of the 21st century. Quality Social Studies Education for sustainable development is significantly necessary for today's Nigeria in post-covid-19. The paper pointed out that the Internet can be used for quality Social Studies Education for sustainable development in Nigeria. Suggestions on how to use the Internet for quality Social Studies Education for sustainable development were made. The paper employed a qualitative study approach. It discussed the Internet and quality Social Studies Education for sustainable development. It further discusses Social Studies Education and the concept of the Internet. It also looked at various scholars' views on sustainable development. It went further to x-rayed the interaction with the Internet and the Internet for quality Social Studies Education for sustainable development. These include, among others, exposure of Social Studies teachers to internet usage for quality Social Studies Education for sustainable development and making school Net, Nigeria Dig Net a reality in Nigeria.
\end{abstract}

Keywords: Social Studies Education; The Internet; Quality Social Studies Education; Sustainable Development; Covid-19

How to Cite: Obro, S. (2021). The Internet and Quality Social Studies Education for Sustainable Development in Post-Covid-19: A Review. Jurnal Penelitian dan Pengkajian Ilmu Pendidikan: e-Saintika, 5(1), 15-26. doi:https:// doi.org/10.36312/e-saintika.v5i1.425

\section{INTRODUCTION}

As the world changes, facts and knowledge change rapidly. Teaching and learning activity in schools also have to change. Momentous changes in research and studies about curriculum development and instructional methods in Social Studies Education are tasking to traditional and conventional thinking in Social Studies teaching. Not an iota of these changes a challenge as the swift development of electronic communication and computer technology. Specifically, the Internet, an easily accessible means of electronic interaction and research, and computer technology and electronic communication components may improve education quality and transform, institutionalise new and innovative methods to teaching and learning. Internet application in education can enhance education quality through the expansion of learning opportunities and education accessibility. Due to these advantages, the National Council on Education supported computer technology utilisation in schools in the 1987 meeting (Federal Republic of Nigeria, 2013). According to Pechman (1992), Associations for Curriculum Development and 
Teachers of Mathematics supported the moving away from direct and teacheroriented instruction toward active, innovative teaching. This method is equally applicable to Social Studies Education from basic level to tertiary institutions education.

In enhancing education (Social Studies Education inclusive) for sustainable growth and development in Nigeria, School Net Nigeria, which is internet services in schools, was launched in September 2001 (Federal Ministry of Education, 2005). School Net Nigeria resulted in students and teachers' learning communities utilising the Internet to enhance educational development in the country (FRN, 2013). Therefore, improving the quality of Social Studies using the Internet for effective teaching and learning to promote sustainable development is essential. There is a need to stimulate ways to promote problem-solving skills, critical and innovative thinking skills. Passive, teacher inculcation of facts, skills and direct instruction as an acceptable teaching approach in Social Studies Education should give way to active and studentcentred approaches to replace conventional or outdated methods. These active approaches should be employed using the Internet through social media for interaction between teachers and teachers, students and teachers, and students and students. Also the delivery of lectures, content materials, assignments, reading, writing, observing, debating, and use of statistical data to advance critical or high order thinking, proffering solution to problems as well as decision-making skills through the utilisation of internet materials such as internet sources, historical maps, literature, computer software, artefacts, photographs, films, computers, and television, that assists in learning (Iboro, 2016).

The outbreak of the Covid-19 pandemic affected all facets of human endeavour worldwide, including education. The pandemic's veracity was challenging and difficult to bear, and the educational sector, Social Studies education inclusive, was the worst-hit by the pandemic. As part of means and measures to control the spread of the Covid-19 pandemic in Nigeria, the government ordered schools' closure, including tertiary institutions. The pandemic no doubt unmasked considerable lapses in the educational sector (Agbele \& Oyelade, 2020). According to Sambo, Oyelade and Ibrahim (2020), schools closure disrupted the teaching and learning process in the country and affected lots of assessment and examinations period - both local, national and international examinations. The implications were that millions of students were forced to defer their studies to a later year.

COVID-19 schools closure led to the suspension of teaching and learning, internal, external, and semesters of Social Studies Education examinations from basic level 1 to tertiaries institutions. It also affected the academic calendar programme of Social Studies Education in Nigerian schools across the nation for significant school activities, and examinations were postponed.

Social Studies Education is an integrated subject that study man and the outcome of man's interactions in his numerous environment. Though Social Studies Education is designed to impart knowledge and provide useful information essential for life, its vital function is to help inculcate and promote students' desired values, attitudes, and social habits. It also includes valuable skills required for the survival of the individuals in society and the world (Odor \& Nwaham, 2005). 
The Internet, Shitta (2002) explained, connects and transforms the world into a global village where people without difficulty get in contact, see, touch, connect and interact with one another, share ideas and information instantly and swiftly from where they are located to other parts of the world. Eze (2012) saw the Internet as an abbreviation for international network communication. The Internet is the largest computer network globally, linking millions of computers. It is also known as the Information Super Highway. The Internet is a non-commercial worldwide network of networks, some of which focus on education.

Social Studies Education quality improvement through the Internet would replace traditional teaching methods that support the principal theory of teacher transmitting or transferring knowledge to learners and learners trustily absorbing this knowledge or information (Green, 2001). Changing the manner and way students think and promote and advance higher-order/critical thinking skills presents a severe challenge to teachers. Mere dependence on the use of sources, artefacts, historical maps, and data sets and the like is not enough. Pechman (1992) asserted that schools attempt to impart students on the usage of standard tools of academic disciplines. Still, many students find limited opportunities or chances outside of school to apply skills and knowledge inculcated. The consequent of the inauthenticity of the learning activity is that students find it challenging to apply learning experiences to their lives. One solution to this problem is improving the quality of Social Studies education through the use of the Internet for better engagement of students' interests on issues and affairs in their immediate environment and globally.

A discourse of possible association or link between the Internet and quality Social Studies education must begin with the obvious: Which or whatever name it is called, this is an Internet era. We are all part of this era. Whether an Internet fanatic or addict who shuns his friends and family to surf the Internet or a computer-hater who at his convenience enjoys using his Automated Teller Machine (ATM) or other electronic credit cards in paying for goods and services. Internet usage offers the opportunity to transform how Social Studies students work and think (Iboro, 2016). Internet utilisation for quality Social Studies Education teaching, for example, will enhance and stimulate students interest in the written words as they explore the Internet for documents in distant and remote libraries. Using databases allows students to independently gather, analyse, interpret, and evaluate their work. Peck and Dorricott (1994) stressed that with few exemptions, students' domains of earthling or discovering materials during school hours are restricted to the classroom. However, through the Internet, students have easy, cheap, prompt and direct access and contact to the world beyond their classrooms, communities and practically any other existing or known boundaries. Thus, while still at school, they can acquire knowledge beyond their communities' boundaries and experiences and gain first-hand knowledge of different cultures.

In recent times, most conferences themes in Social Studies for about a decade now have focused on improving quality Social Studies and sustainable development. These conference themes reflect the increasing consciousness that enhancing the quality of Social Studies Education is vital not only for a lively nation's sustenance but also to maintain national development. Researchers such as Iboro (2016), Gurcan (2015), Okobia (2015), Goodyear, Casey and Krik (2014), Menkhoff, Chay, Bengtsson, 
Woodard and Gan, 2014 and Atubi and Obro (2020) stressed that forms of technologies such as social media (Whatsapp, Messenger, Facebook, Twitter, blogs) could together be a stimulus to both students and teachers. This would enable them to participate actively, contribute and communicate with one another on educational issues and activities. Dzvapatsvia, Mitrovic, and Dietrich (2014) argued the internet technologies which have grown and become widespread could enhance traditional teaching methods. Chawinga and Zinn (2016) opined that the most popular internet technologies include but not limited to the social media sites like Facebook, LinkedIn, wikis, MySpace, Flickr and Tumblr; YouTube, Twitter, and blogs, etc.

Studies have indicated that Facebooking, tweeting, whatsapping, and blogging are more exciting and interactive instruction and learning ways than passive and traditional teaching or knowledge transfer medium (Karchmer, 2010). Yunita, Nursechafia, Setiawan and Nugroho (2018) in their study revealed that the useage of mobile phone application such as Facebook, zoom, webnar, whatsapp, etc improve students performance and students were excited using these applications for their study. Dwikoranto, Setiani, Prahani and Mubarok (2020) in their study on the use of nobile learning to improve students skills reported that students positively responded to the use of mobile learning of whatsapping, Webinar and Zoom Meeting and google group. Halil (2020) in the study on the effect of Edmodo as online learning tool in during covid-19, observed enhanced students performance and that students enthusiastic in using the tool for learning.

Within the paradoxical themes (rapid and unforeseeable internet impact and caution founded on unfulfilled outcomes and expectations), what is Social Studies Education prospect in the era of internet knowledge and distributed intelligence? Against this background, this paper presented a discussion on the Internet and quality Social Studies Education for sustainable development. To give more profound concern and insight into this study's problem, the following were addressed: concept of Social Studies Education, the concept of the Internet, sustainable development. It went further to x-ray the interaction with the Internet and the Internet and quality Social Studies Education for sustainable development.

\section{CONCEPTUAL BACKGROUND}

\section{Social Studies Education}

Social Studies as a course of study differs from one country to another in terms of conceptualisation, scope, content and application. This is based on the objectives it is set to attain in such a country. The concept, thus, marks out the scope and content of the subject in any country it is embraced (Ezegbe, 2012). Okan (2002) expatiated that Social Studies is meant to lead and guide the individual to discover motivation, interest and excitement in the process of social living and education through exploration, investigation, inquiry and discovery. It is concerned with the timely and necessary use of curriculum content that students see as appropriate but principally stressed the need to help students build the skills and attitude vital for democratic living (Atubi, 2019).

It cut across exploiting man's environment to desired skills and competencies needed to protect and preserve man's environment. Social Studies Education is chiefly interested in the study of man and the environment in which he lives, where and how 
he lives, how man govern himself and the formation of societal structures and institutions for the greater good and betterment of society in which he lives (Onyeaghor, 2015). According to Nzegbulem (2014), Social Studies Education main objective is to help the youths make knowledgeable and logical decisions for societal good as members of a multi-ethnic or society with diverse cultures in an interdependent world. Social Studies education inculcates the learners the desirable skills, attitudes and values to become valuable and active citizens who are nationally conscious and responsive to their country's challenges. The nature of Social Studies Education is that of a spiral and incessantly expanding curriculum in areas of content or subject matter enrichment and integration with contemporary or current emerging events/issues (Mezieobi, 2012). Improving quality Social Studies Education depicts the inculcation of the right type of values, the functionality of teachers' operational skills, and the capability to implement the Social Studies Education curriculum to accomplish sustainable development.

\section{The Internet}

The word Internet originates from the words "Internet Connection Network". The Internet has been the greatest and one of the revolutionary inventions of the late 20th century. The Internet is a global or worldwide linking of computers that allows and involves information transfer (Schneider, Evans \& Pinard, 2006). To Iyendo and Halil (2015), the Internet is an electronic network that links computer networks worldwide. In its submission, the World Telecommunication Policy Forum (2013) defined the Internet as an international collection of connected telecommunication networks that available for the interface of corresponding data and information systems; and their users, through transporting of information traffic employing a protocol, a single system of identification, naming, actions, addressing, numbering, and so on. This definition did not include the applications and services the Internet offers on the network but only the network itself. The United States Federal Networking Council (USFNC) (1995) emphasised that the Internet is logically connected by a universally or globally distinct address space supported on the Internet Protocol (IP). This is a very comprehensive definition because it incorporates the applications and devices that operate on the IP/TCP protocol, likewise the hardware linked by that protocol. This comprehensive description would seem to correspond well to what is generally meant by the Internet.

The types of services convey by the Internet are countless. Among the services rendered, e-mail is the most popular. Others are the world wide web (WWW), file transfer protocol (FTP), voice traffic, file sharing and newsgroups ${ }^{2}$. With computers, digital assistants that use dial-up, landline broadband, terrestrial wireless, mobile phones and satellite links devices, the internet services can be accessed. At present, it had profound effects on several areas of human endeavour, and, in the views of many scholars and professionals, the Internet transformation has just started (Apuke \& Iyendo, 2017).

\section{Interaction with the Internet: Counting the Ways}

- E-mail: Teachers and students can co-operate and collaborate with each and one another through this medium. 
- File Transfer- This tolerates the transfer of files and information by teachers and students from one computer to another.

- USENET- a discussion and information service on practically any possible subject matter or topic for people globally to provide information in reply to others' questions and issues.

- Archie- a database/file system that often calls libraries to find out what is currently available. An automatic and programmed updating system with over a thousand file libraries. With a full or abbreviated file name, it directs the user to where the file is located.

- Gopher- is a vast Internet menu arrangement. Files and folders containing Information about practically any subject matter are housed in thousands of locations.

- Veronica: This is a search engine device or instrument for the search and location of museums available on the Internet.

- Wide Area Information Server: - This is similar to the index that helps scan and finds data in the internet networks.

- ListServs (List service)- This is an automatic or programmed mailing list for members of a unique interest organisation or group interested in a similar topic. Students and teachers can sign up for a specific service, and a host computer or device will automatically make available the updated information to beneficiaries each day.

- Social networking sites (Social Media): this include Twitter, Facebook, LinkedIn and MySpace; media sharing sites, like YouTube, Flickr and Tumblr; wikis and blogs and syndication of content through Rich Site Summary (RSS) feeds.

\section{Sustainable Development}

Formerly, attention was chiefly on the concept of development, but there was a shift in awareness when the Bruntland Commission reshaped and modified the concept to Sustainable Development. In numerous ways, sustainable development is conceptualised. Still, the most regularly cited definition is from the Bruntland Report (2013), which asserted that sustainable development meets the present devoid desires of disrupting future generations' ability to meet their needs. It connotes the concern for social and economic security, good health, and the environment socially and physically (Akpama, Bessong \& Bessong, 2017; Atubi, 2020).

For Shittu (2017), sustainable development has to do with ensuring the satisfaction of the needs of the present generation and national resources are not depleted or endangered to satisfy the needs of future growth and protect the livelihoods of future generations (Kayode, 2012). This implies it guarantees the national resources and economic destiny, not to mortgage future generations' needs unjustly. Akinjide (2011) expatiated that sustainable development ensures the creation of national health, economical progress, prosperity, democratic, a classless and better society, based on equitable or just distribution of resources to bring about social justice, fairness and dignity of the human person. According to Leonardi (2010), sustainable development, in addition to clamouring for political, cultural and socioeconomic order transformation, also stresses a change in the attitude of humanity who desire the development of a more compound and multidisciplinary vision or foresight 
on development aiming to make available the condition needed for the society attain it.

Babavvale (2007) defined sustainable development as a careful and systematic plan and policy of ensuring the nation's survival and how the political and socioeconomic prerequisites are essential for the enjoyment of quality life currently guaranteed for the future generation. In view of Šlaus and Jacobs (2011), sustainable development is a moral principle and a scientific concept. Sustainable development entails that all programmes and policies should be for societal well-being, with a positive effect on preserving and sustaining balance in the pursuit of growth and improving the people's quality of life (Ogbo, Eneh, Agbaeze, Chukwu \& Isijola, 2017).

To be sustainable, growth and development must combine three core statements: fairness, environmental protection and efficiency; this indicates the preservation or security of the socio-economic and ecological balance in the use of natural and human resources (Legrand Report, 2012). The motivating aspect or part of sustainable development is that it considers people's present circumstances without compromising that of the future ones (Atubi, 2020). Therefore, sustainable development's concept and principle continue to be the modern parameter or yardstick of measuring development.

\section{The Internet and Quality Social Studies Education for Sustainable Development in Post Covid-19}

The primary goal and objective of Social Studies Education is to produce welltrained citizens, effective and equipped, and willing to be involved and participate in democratic life (Kaya, 2008). According to the day's conditions, this type or sort of citizens are actively engaged in individual and social activities and can answer the questions passed to them by filtering the information coming from the social environment (Sunal \& Haas, 2005). Social Studies Education classes aim to revise social planning thoroughly and make students ready to meet society. For this reason, teachers and students must be prepared for the informational revolution and the effects of the Internet in society (Kaya, 2008). Right at this point, one may claim that using the Internet, just like any other educational resources, will help not only Social Studies Education but also for sustainable development. One may argue that using the Internet to bring about quality of Social Studies education for sustainable development has become important in recent times and years.

Bolick (2002) identified three main categories in which the Internet would help improve Social Studies Education's quality for sustainable development as cooperative communication, data collection, and multimedia activities. The utilisation of the Internet in Social Studies Education instructions would facilitate and motivate students' active involvement in exploring information that can help solve real-life situations and problems (Okoye \& Udegbe 2004). Thus, programmed and documented Social Studies Education teaching utilising the Internet would assist students in their learning process. For pertinent and vital data, ideas, knowledge, skills, learning experiences, thought-provoking and higher-order drills are disseminated through the Internet for the benefit of users (learners) (Nnabuo \& Asodike (2016).

Since the kind of quality Social Studies Education desired and believe could bring about national development that could be sustained has not been attained, 
improving quality Social Studies Education is necessary. There is no doubt that effective and quality Social Studies Education through the Internet application can serve as a means or vehicle for sustainable development. Simultaneously, teachers are cautioned against embracing the Internet with abandon. They are advised on using the Internet as religion, that is, on an unexamined commitment to the Internet (Shaver, 2018).

Riti and Kamah (2015) reported that using the Internet, the smart board, social media, and web resources would improve Social Studies Education's sustainable development quality. When adopted appropriately for academics, the Internet is a transformational tool that would promote and change Social Studies Education teaching, particularly at this time of educational expansion. Availability and application of the Internet in the classroom may stimulate quality Social Studies Education for sustainable development. It helps teachers interact with their students, fellow teachers, and the world in general through social media, e-mail and other Internet components. Specifically, the Internet, an accessible means and channel of electronic interaction, may not only stimulate quality Social Studies Education but further transform and even institutionalise these new and innovative methods to Social Studies teaching (Bolick, 2002). The use of the Internet can improve Social Studies Education quality by expanding learning opportunities and education accessibility. With the Internet coupled with the worldwide web- a wealth of learning resources in practically all content or subject matter and a variety of media, can be accessed from anywhere, all round the clock and by an unrestricted number of people; felicitation of accessibility to Social Studies Education experts, resource persons, researchers, teachers, students, so on, will result to quality Social Studies Education for sustainable development.

\section{CONCLUSION}

The contemporary conception of sustainable development is only meaningful when every citizen participates in society's economic and social development. It is anticipated that quality Social Studies Education for sustainable development can be achieved using the Internet. The Internet offers variability of micro-electronic based devices that can bring about quality Social Studies Education for sustainable development. Social Studies teachers' ability to effectively deploy the Internet for classroom use is pertinent to improving quality Social Studies Education for sustainable development. Social Studies Education will enhance the process and path of sustainable growth and development in Nigeria through the Internet. Internet application or usage for learning can stimulate and accelerate students' problemsolving, data processing, decision-making skills, and communication capabilities. The application of the Internet can bring about improved quality Social Studies Education for sustainable development in Nigeria in post-Covid-19. Social Studies Education teachers should be exposed to in-service training to learn how to use the Internet for improving quality Social Studies Education for sustainable development. The school Net, Nigeria Dig Net, should be made a reality. Social Studies Education teachers should be encouraged by making available internet services in their school environment. Adequate internet facilities and service should be provided for Social Studies Education teachers and students for easy internet accessibility. There should 
be curriculum review to promote and facilitate a compulsory internet-driven curriculum in Nigeria.

\section{ACKNOWLEDGEMENT}

The author did not grant from any funding agency in the commercial, public, or non-governmental organisations sectors. However, the author acknowledges lecturers and social studies students in social science education, Delta State University, Abraka, Nigeria. Professor Willims Pius Akpochafo, Mrs Favour Onamrewo Atubi and Afuruku, Ebiotu for their support, encouragement, and other contributions to the study success.

\section{REFERENCES}

Akinjide, A. (2011). Education for social reconstruction: Implication for sustainable development in Nigeria. International Journal of Humanities and Social Sciences, 1(21), 84-91. http://www.ijhssnet.com/journals/Vol_1_No_21_Special_Issue_ December_2011/10.pdf

Akpama, S. I., Bessong, C. D., \& Bessong, N. O. (2017). Attainment of the sustainable development goals (SDGs): The relevance of adult basic education. Education for Today, 13(1), 13-19.

Agbele, A. T., \& Oyelade, A. E. (2020). Impact of COVID-19 on the Nigerian educational system: Strengths and challenges of online/virtual education. Asian Journal of Education and Social Studies, 13(1), 26-35. https://doi.org/10.9734/ AJESS/2020/v13i130322

Apuke, O. D., \& Iyendo, T. O. (2017). Two sides of a coin: revisiting the impact of social networking sites on students' performance in selected higher educational settings in Nigeria. Sci. Int. 29(6), 1265-1275. https://www.researchgate.net/ publication/322701558_Two_Sides_of_a_Coin_Revisiting_the_Impact_of_Socia 1_Networking_Sites_on_Students'_Performance_in_Selected_Higher_Education al_Settings_in_Nigeria

Atubi, F. O. (2019). Community resources and effective teaching of upper basic social studies in Delta State. Nigerian Journal of Social Studies, 22(2), 172-180. https:// www.google.com/url?sa=t\&source=web\&rct=j\&url=https:/ / www.sosan.org.n $\mathrm{g} /$ njss/publications/VOL_XXII_2_OCTOBER_2019.pdf\&ved=2ahUKEwjqn66q 5_pAhVfDWMBHUu3DLkQFjAEegQIAxAB\&usg=AOvVaw1_yg_tbjWU7Uou QoLvVCjC

Atubi, F. O. (2020). Sustainable development goals: Why quality education should top the agenda. Journal of Social and Management Sciences, 14(2), 68-77. https://www. university journals.org $>$ jsms

Atubi, F. O., \& Obro, S. (2020). Covid-19 pandemic lockdown and the upsurge of online learning: prospects for social studies in Nigeria. Journal of the Social Sciences, 48(3),4001-4011. https://www.researchgate.net/publication/3442699 11_Covid-19_pandemic_lockdown_and_the_upsurge_of_online_learning_pros pects_for_social_studies_in_Nigeria

Babawale, T. (2007). Culture, politics and sustainable development: Lessons for Nigeria in occasional monograph)' series of Centre for Black and African Arts and Civilization. Concept Publications Ltd. https://scholar.google.com/scholar?cluster=564230 $6330779760307 \&$ hl=en\&oi $=$ scholarr 
Bolick, C. M. (2002). Digital History TIP. Journal of Computing in Teacher Education, 19(2), 54-60, DOI: 10.1080/10402454.2002.10784462

Bruntland Report (2013) Brundtland Commission (1987). Report of the World Commission on Environment and Development. United Nations.

Chawinga, W. D., \& Zinn, S. (2016). Use of Web 2.0 by students in the Faculty of Information Science and Communications at Mzuzu University, Malawi. South African Journal of Information Management, 18(1), 1-10.https:/ / sajim.co.za/index. php/sajim/article/view/694/901

Coronel, D. A., Alves da Silva, J. M., \& Leonardi, A. (2010). Hermeneutical and philosophical consideration about ethics and sustainable development. Global Journal of Human Social Studies, 10, (2), 30-37. <https:// socialscienceresearch.org/ index.php/GJHSS/article/view/12>

Dwikoranto, D., Setiani, R., Prahani, B. K., Mubarok, H. (2020). Mobile learning to improve student collaborative skills: An alternative to online learning in the era of Covid-19 pandemic. Jurnal Penelitian dan Pengkajian Ilmu Pendidikan: e-Saintika, 4(3), 259-271. https:// doi.org/10.36312/e-saintika.v4i3.314

Dzvapatsva, G. P., Mitrovic, Z., \& Dietrich, A. D. (2014). Use of social media platforms for improving academic performance at Further Education and Training Colleges. South African Journal of Information Management, 16(1), 1-7. https:// sajim.co.za/index.php/sajim/article/view/604/757

Eze, J. U. (2012). Perceptions and willingness to e-learning secondary school teachers in Nsukka Education Zone of Enugu State, Nigeria. Journal of Home Economics Research, 16, 79-89.

Ezegbe, M. O. (2012). Foundations of Social Studies. Danton Publishers.

Federal Ministry of Education (2005). School Net Nigeria. FME.

Federal Republic of Nigeria (2004). National Policy on Education. Federal Government Press.

Federal Republic of Nigeria. (2013). National Policy on Education. FME

Goodyear VA, Casey A, Krik D. (2014). Tweet me, message me, like me: using social media to facilitate pedagogical change within an emerging community of practice. Sport, Education and Society, 19(7), 927-43.

Green, T. (2001). Tech talk for social studies teacher: Virtual expeditions: Taking your students around the world without leaving the classroom. The Social Studies 92(4), 177-179.

Gurcan, H. I. (2015). Contribution of Social Media to the Students' Academic Development. International Journal of Information and Education Technology, 5(12), 965-972.

Halil, N., I. (2020). The Effectiveness of Using Edmodo as an Online Learning Platform in Covid-19. Jurnal Penelitian dan Pengkajian Ilmu Pendidikan: e-Saintika, 4(3), 284-298. doi:https:/ / doi.org/10.36312/ e-saintika.v4i3.316

Iboro, O. U. (2016). Examination of ICT compliance and utilisation for curriculum delivery among social studies teachers in Nigeria. International Journal of Education, Learning and Development,.4(7), 1-10.

Iyendo, O. T., \& Halil, Z. A. (2015). Computer aided design (cad) technology versus students' learning in architectural design pedagogy- A controversial topic review. International Journal of Development Research, 5(01), 3152-3158. 
Karchmer, R. A. (2001). The Journey Ahead: Thirteen Teachers Report on How the Internet Influences Literacy and Literacy Instruction in Their K-12 Classrooms. Reading Research Quarterly, 36, 442-466.

Kaya, B. (2008). Sosyal Bilgiler Dersinde Teknoloji Kullanımı, GÜ, Gazi Eğitim Fakültesi Dergisi, Cilt 28, Sayı 3,189-205.

Kayode, O. (9 July, 2012). Towards economic diversification and sustainable development. Business Day Newspaper. Monday,.

Legrand Report (2012) Sustainable Development: Definition, Background, Issues and Objectives. http:/ / www.legrand.com/EN/ sustainable-development-descriptio n_ 12847.html

Menkhoff, T., Chay, Y. W., Bengtsson, M L., Woodard, C. J., \& Gan, B. (2015). Incorporating microblogging ("tweeting") in higher education: lessons learnt in a Knowledge Management Course. Computers in Human Behavior, 51, 1295-1302.

Mezieobi, D. I. (2012). Teaching practice in social studies education in Nigeria. Gabteny Publishers.

Nnabuo, P. O. M., \& Asodike, J. D. Exploring education as a tool for sustainable development in Nigeria. European Scientific Journal, 8(10)1-11.

Odor, G., \& Nwaham, C. (2005). Introduction to social studies. Krisbec Publication.

Ogbo, A. I., Eneh, N. C. J., Agbaeze, E. K., Chukwu, B. I., \& Isijola, D. O. (2017). Strategies for achieving sustainable economy in Nigeria taking into consideration the acceptable stakeholders. African Journal of Business Management, 11(19), 582589.

Okam, C. C. (2012). Needed paradigm shift for repositioning social studies education to meet vision 20:20:20 challenges in Nigeria. Nigerian Journal of Social Studies, 15(2), 15-39.

Okobia, E. O. (2015). Changing teachers roles in emergent innovations in Nigeria schools. Nigerian Educational Researcher, 20(20), 67-72.

Okoye, F. N., \& Udegbe, G. B. (2004). The need for ICT in science education: teachers perspective. Paper presented at the Annual National Conference on ICT and Enhancement of Education in the 21st Century, Federal College of Education (Technical) Umunze, Anambra State. Nigeria.

Onyeaghor, I. A. (2015). Social studied students' perception of goals, content and teaching strategies of Social Studies in College of Education in Edo and Delta States. An unpublished thesis, Delta University, Abraka.

Pechman, E. M. (1992) Child as Meaning Maker: The Organizing Theme for Professional Practice Schools. In M. Levine (Edited) Professional Practice Schools. Teachers College Press.

Peck, K. L., \& Dorricott, D. (1994). Why Use Technology? Educational Leadership, 51, 1115.

Riti, J. S., \& Kamah, M. (2015). Entrepreneurship, employment and sustainable development in Nigeria. International Journal of Academic Research in Economics and Management Sciences, 4 (1), 179-199.

Sambo, M. A. H., Oyelade, E. A., \& Ibrahim, M. O.(2020). Senior Secondary School science students' perceptions of learning environment and its relationship to achievement in biology. Lafia Journal of Education, 1(3), 290-303. 
Schneider, G. P., Evans, J., \& Pinard, K. T. (2006). The Internet Fourth Edition- Illustrated Introductory (4th Ed.). Thomson Course Technology

Shitta, M. B. K. (2002). The impact of information technology on vocational and technology education for self-reliance. Journal of VOC E Tech. Education, 1(1), 7582.

Shittu, J. (2017). Towards achieving sustainable development for all: Prioritising targets for implementation: which way forward for Nigeria? Center for Public Policy Alternatives.

Šlaus, I., \& Jacobs, G. (2011). Human capital and sustainability. Sustainability, 3, 97154.

Sunal, C. S., \& Haas, M. E. (2005). Social Studies for the Elementary and Middle Grades. Pearson Education İnc.

United States Federal Networking Council (USFNC) (1995,) 1 FNC Resolution. http://www.hpcc.gov/fnc/Internet_res.html

World Telecommunication Policy Forum (2013). Defining the Internet. http://www.itu. Int/md/ S13-WTPF13IEG3-C-0049/en

Yunita, A., Nursechafia, Setiawan, E., \& Nugroho, H. (2018). The relationship between mobile phone usage in classroom and academic achievement in college life. International Journal of Interactive Mobile Technologies, 12(8), 96-103. 